\title{
Tinjauan Keadilan, Kepastian Hukum, dan Kemanfaatan dalam Penerapan Peraturan Pemerintah Nomor 24 Tahun 2018 tentang Pelayanan Berusaha Terintegrasi Secara Elektronik
}

Raden Mas Try Ananto Djoko Wicaksono; Fakultas Hukum, Universitas Gadjah Mada, Jl. Dr. Saharjo No. 83, Manggarai, Kota Jakarta Selatan, 12850; E-mail: radenmas96@mail.ugm.ac.id

\begin{abstract}
Abstrak
Penelitian ini melakukan tinjauan hukum terhadap Peraturan Pemerintah Nomor 24 Tahun 2018 sebagai cikal bakal terbentuknya Online Single Submission (OSS). Bertujuan menganalisis unsur keadilan, kepastian hokum, dan kemanfaatan sesuai dengan tujuan terbentuknya hukum, ditinjau dengan Asas Umum Pemerintahan yang Baik berdasarkan Undang-Undang Nomor 25 Tahun 2009 tentang Pelayanan Publik dan Undang-Undang Nomor 30 Tahun 2014 tentang Administrasi Pemerintahan mengenai penerapan OSS ini. Penelitian ini merupakan penelitian yuridis normatif dengan teknik pengumpulan bahan dari kepustakaan yang terdiri dari bahan hukum primer dan sekunder. Hasil penelitian menunjukkan bahwa penerapan dan berlakunya OSS atas dasar Peraturan Pemerintah Nomor 24 Tahun 2018 tentang Pelayanan Perizinan Berusaha Terintegrasi Secara Elektronik tidak sesuai dengan tujuan hukum. Hal tersebut dikarenakan tidak adanya masa transisi dalam pemberlakuan peraturannya dan memberi kesempatan bagi masyarakat dan/atau pelaku usaha untuk belajar dan menyesuaikan dengan sistem yang benar-benar baru dalam dunia perizinan berusaha. Disisi lain, adanya tumpang tindih antara peraturan satu dengan peraturan lainnya yang mana menyebabkan ketidakpastian hukum yang kemudian berpengaruh kepada kemanfaatan hukum itu sendiri.
\end{abstract}

Kata Kunci: Keadilan Hukum, Kepastian Hukum, Kemanfaatan Hukum, Online Single Submission, Peraturan Pemerintah Nomor 24 Tahun 2018, Perizinan Berusaha

\begin{abstract}
This study conducted a legal review of Government Regulation Number 24 of 2018 as the forerunner to the formation of OSS. The aims is to analyze the elements of justice, legal certainty and legal expediency in accordance with the objectives of the formation of law and to be reviewed with related regulations such as the General Principles of Good Governance based on Law Number 25 of 2009 concerning Public Services and Law Number 30 of 2014 concerning Government Administration regarding the implementation of this OSS. This research is a normative juridical research with the data collection technique from literature studies consisting of primary and secondary legal materials. The results show that the application and enactment of OSS on the basis of Government Regulation Number 24 of 2018 concerning Electronically Integrated Business Licensing Services is not in accordance with legal objectives. This is due to the absence of a transition period in the enactment of the regulations and provides an opportunity for the community and / or business actors to learn and adapt to a system that is completely new in the business licensing world. On the other hand, there is an overlap between one regulation and another, that causes legal uncertainty and later affects the expediency of the law itself.
\end{abstract}

Keywords: Legal Justice, Legal Certainty, Legal Expediency, Online Single Submission, Government Regulation Number 24 of 2018, Business Licensing 


\section{PENDAHULUAN}

\section{Latar Belakang}

Pemerintah Indonesia melalui Peraturan Pemerintah Nomor 24 Tahun 2018 tentang Pelayanan Perizinan Berusaha Terintegrasi secara Elektronik (selanjutnya disebut PP 24/2018) memberikan kemudahan perizinan berusaha yang terintegrasi secara elektronik atau lebih dikenal sebagai Online Single Submission (OSS) yang mana diarahkan untuk deras dan peningkatan penanaman modal dan berusaha serta mempermudah pelaku usaha, baik perorangan ataupun non-perorangan.

Secara teknis OSS memiliki keunggulan dalam kemudahan mengajukan permohonan perizinan secara online melalui laman oss.go.id. OSS ini merubah paradigma perizinan di Indonesia, yang sebelumnya diajukan secara konvensional dengan datang ke loket perizinan dengan menyerahkan berkas, sekarang hanya cukup bermodalkan komputer atau gadget yang tersambung internet semua orang bisa dengan mudah melakukan perizinan baik perseorangan maupun non-perseorangan (badan usaha).

Berjalannya OSS dalam bentuk kemudahan berusaha atau ease of doing business (EODB) memiliki pengaruh yang bermakna dalam meingkatkan peringkat kemudahan perizinan di Indonesia. ${ }^{1}$ Sesuai dengan data yang publikasi oleh Bank Dunia dengan berlakunya OSS indicator starting a business, Indonesia meningkat pada peringkat ke-10 dari 144 menjadi $134 .^{2}$ Akan tetapi, setelah berjalannya 1 (satu) tahun OSS, peringkat EODB Indonesia tertahan di peringkat 73. Bank Dunia menjelaskan penyebab Indonesia tertahan di peringkat 73 dikarenakan Indonesia memiliki regulasi ketenagakerjaan yang paling rigid dibanding negara-negara lainnya, terutama dengan pengangkatan kerja. Disisi lain, tertahannya peringkat Indonesia ini dapat disebabkan oleh output dari OSS tersebut. Impelementasi PP 24/2018 sebagai cikal bakal terbentuknya OSS sejauh ini masih menemukan kendala dalam penerapannya. ${ }^{3}$

Kendala yang terjadi adalah tidak adanya masa transisi dalam pelaksanaan PP 24/2018 dimana peraturan tersebut langsung berlaku saat itu juga setelah di undangkan. Ditambah belum terintegrasinya sistem perizinan di tingkat pusat seperti Kementerian atau Lembaga (K/L) dengan OSS. Ditambah beberapa wilayah daerah di Indonesia juga menerapkan sistem perizinan mandiri berbasis aplikasi atau Pelayanan Terpadu Satu Pintu (PTSP) yang belum terintegrasi dengan OSS. Hal tersebut didasari karena sistem komputer antar K/L, baik di pusat ataupun daerah yang belum terkoneksi dengan baik. Kepala Seksi (Kasi) Dukungan Teknis Sistem BKPM, Fitriana Aghita Pratama

\footnotetext{
${ }^{1}$ Desi Arianing Arrum. (2019). 'Kepastian Hukum dalam Perizinan Berusaha Terintegrasi Secara Elektronik (Online Single Submission) di Indonesia', Jurist-Diction 2, No. 5: 1631, https://doi.org/10.20473/jd.v2i5.15222.

2 Prima Wirayani, 'Ease of Doing Business RI Turun, Ini Penjelasan Bank Dunia', CNBC Indonesia, 2018, https:// www.cnbcindonesia.com/news/20181031201049-4-40020/ease-of-doing-business-riturun-ini-penjelasan-bank-dunia.

3 Arif Gunawan, 'Ini Penyebab Peringkat Doing Business Indonesia Mentok di 73', CNBC Indonesia, 2019, https://www.cnbcindonesia.com/news/20191024225303-4-109976/ini-penyebabperingkat-doing-business-indonesia-mentok-di-73/1.
} 
berpendapat bahwa terdapat beberapa permasalahan dengan penerapan OSS khususnya pada tingkat daerah. Beliau berpandapat bahwa masih adanya kendala dalam proses integrasi antara OSS dengan sistem perizinan daerah. Harapannya bahwa setelah proses integrasi tersebut rampung diharapkan seluruh perizinan dilakukan melalui OSS. ${ }^{4}$

Adapun permasalahan mengenai Norma, Standar, Prosedur dan Kriteria (NSPK). Menurut Boedi Rheza selaku peneliti dari Komisi Pemantauan Pelaksanaan Otonimo Daerah (KPPOD) menjelaskan bahwa NSPK yang merupakan petunjuk teknis pelayanan perizinan justru tidak actual menerjemahkan PP 24/2018. Salah satunya ialah kasus persoalan NSPK ketika pelaku usaha ingin mendapatkan izin usaha industri (IUI). Pelaku usaha pertama-tama perlu mendaftarkan lagi ke aplikasi Sistem Informasi Industri Nasional (SIINAS) milik Kementerian Perindustrian. Sementara itu, aturan OSS menyatakan tidak memerlukan persyaratan tersebut. Akhirnya, terjadi berbagai macam variasi pada SOP pelayanan izin daerah yang justru memusingkan pemerintah daerah dan pelaku usaha. ${ }^{5}$

Melihat permasalah tersebut, Penulis berniat melakukan tinjauan hukum terhadap PP 24/2018 sebagai cikal bakal terbentuknya OSS. Adapun permasalahan yang dirumuskan oleh Penulis, diantaranya apakah penerapan OSS ini sudah memenuhi unsur keadilan, kepastian hukum dan kemanfaatan sesuai dengan tujuan terbentuknya hukum dan ditinjau dengan peraturan terkait seperti Asas Umum Pemerintahan yang Baik sesuai dengan Undang-Undang Nomor 25 Tahun 2009 tentang Pelayanan Publik dan Undang-Undang Nomor 30 Tahun 2014 tentang Administrasi Pemerintahan (UU 30/2014) mengenai penerapan OSS ini.

\section{METODE PENELITIAN}

Penelitian ini menganalisis menggunakan yuridis normative. Menurut Soekanto dan Mamudhi, penelitian normatif ialah penelitian yang dilakukan dengan cara meneliti bahan pustaka atau data sekunder. ${ }^{6}$ Menurut Peter Mahmud Marzuki, penelitian hukum normatif ialah suatu proses yang mana bertujuan mendapatkan suatu aturan hukum, prinsip-prinsip hukum, ataupun doktrin-doktrin hukum yang betujuan untuk menjawab suatu isu hukum yang dihadapi. ${ }^{7}$ Penelitian ini bermaksud untuk menyajikan pendapat hukum sebagai dasar penentu atas suatu kejadian untuk menentukan kesesuaian sudah sesuai atau belum kesesuaian serta bagaimana sebaiknya kerjadian tersebut menurut hukum. ${ }^{8}$

\footnotetext{
${ }^{4}$ Mochamad Januar Rizki, ‘Dinilai Tak Maksimal, Aturan OSS Perlu Dievaluasi', Hukum Online, 2019, https://www.hukumonline.com/berita/baca/lt5d78d3507a42d/dinilai-tak-maksimalaturan-oss-perlu-dievaluasi/.

${ }^{5}$ Ibid.

${ }^{6}$ Soerjono Soekanto and Sri Mamudji. (2003). Penelitian Hukum Normatif: Suatu Tinjauan Singkat Jakarta: Raja Grafindo Persada.

7 Peter Mahmud Marzuki. (2010). Penelitian Hukum . Jakarta: Kencana Prenada.

8 Mukti Fajar and Yulianto Achmad. (2013). Dualisme Penelitian Hukum Normatif \& Empiris. Yogyakarta: Pustaka Belajar.
} 
Teknik pengumpulan bahan dari kepustakaan (library research $)^{9}$ meliputi bahan hukum primer dan hukum sekunder. Bahan dari hukum primer terdiri Peraturan Pemerintah Nomor 24 Tahun 2018 tentang Pelayanan Berusaha Terintegrasi Secara Elektronik. Sedangkan bahan sekunder bersifat membantu atau menunjang bahan hukum premier yang meliputi buku, jurnal dan dokumen pendukung lainnya. Terakhir, bahan hukum tersier, yakni pemahaman terhadap hukum primer dan sekunder seperti kamus hukum, ensiklopedia, dan lain-lain.10

\section{PEMBAHASAN}

Secara umum, Online Single Submission (OSS) sesuai dengan Pasal 1 Angka 5 Peraturan Pemerintah Nomor 24 Tahun 2018 tentang Pelayanan Perizinan Berusaha Terintegrasi Secara Elektronik (PP 24/2018) mengartikan bahwa, "Perizinan Berusaha Terintegrasi Secara Elektronik atau OSS adalah Perizinan Berusaha yang diterbitkan oleh Lembaga OSS untuk dan atas nama menteri, pimpinan lembaga, gubernur, atau bupati/wali kota kepada Pelaku Usaha melalui sistem elektronik yang terintegrasi." Adapun yang dimaksud dengan lembaga OSS sesuai dengan Pasal 1 Angka 11 PP 24/2018 yakni: "Lembaga Pengelola dan Penyelenggara OSS yang selanjutnya disebut Lembaga OSS adalah lembaga pemerintah non kementerian yang menyelenggarakan urusan pemerintahan di bidang koordinasi penanaman modal." Adanya Lembaga OSS sendiri memiliki beberapa kewenangan yang berdasarkan Pasal 94 Ayat (1) Lembaga OSS untuk:

a. menerbitkan Perizinan Berusaha melalui sistem OSS;

b. menetapkan kebijakan pelaksanaan Perizinan Berusaha melalui sistem OSS;

c. menetapkan petunjuk pelaksanaan penerbitan Perizinan Berusaha pada sistem OSS;

d. mengelola dan mengembangkan sistem OSS; dan

e. bekerja sama dengan pihak lain dalam pelaksanaan, pengelolaan, dan pengembangan sistem OSS.

Pada dasarnya peraturan ini bertujuan untuk mempermudah proses izin usaha, akan tetapi Sumber Daya Manusia (SDM) pengelola dan sarana maupun prasarana kantor yang masih kurang mendukung dibeberapa daerah di Indonesia, khususnya Indonesia bagian timur. ${ }^{11}$ Kedua hal ini juga berakibat pada rendahnya kinerja atau implementasi layanan OSS. Salah satu permasalahan yang dihadapi yakni kekurang pemahaman oleh pelaku usaha pada sistem, pelaku usaha tidak melakukan pemenuhan komitmen dan sulitnya akses internet.12 Maka, pentingnya tindakan pendampingan serta koordinasi penyelesaian hambatan antara lembaga satu dengan lembaga terkait lainnya.

\footnotetext{
${ }^{9}$ Iqbal Hasan. (2008). Analisis Data Penelitian dengan Statistik. Jakarta: Bumi Aksara.

${ }^{10}$ Saifullah. (2004). Konsep Dasar Metode Penelitian dalam Proposal Skripsi. Malang: UIN Malang.

11 Inri Monica Priscila Meray. (2014). 'Implementasi One Stop Servica (OSS) Dan Pelayanan Perizinan Terpadu (BP2T) Kota Manado', Jurnal Administrasi Publik 1, no. 1: 1-11.

${ }^{12}$ Muhammad Iqbal Fitra Assegaf, Henny Juliani, and Nabiatus Sa'adah. (2019). 'Pelaksanaan Online Single Submission (OSS) dalam Rangka Percepatan Perizinan Berusaha di Dinas Penanaman Modal dan Pelayanan Terpadu Satu Pintu (DPMPTSP) Jawa Tengah', Jurnal Hukum Diponegoro 8, No. 2: $1328-42$.
} 


\section{A. Keadilan dalam Penerapan OSS}

Salah satu tujuan dari terciptanya hukum ialah keadilan. ${ }^{13}$ Keadilan sebagai suatu perasaan sesama yang berhubungan antar manusia satu dengan manusia lainnya. John Rawls berpendapat tentang keadilan yang berkaitan dengan prinsip kebebasan, yakni, kesetaraan atau kesamaan untuk setiap manusia (principle of greatest equal liberty), mengenai hal tersebut John Rawls berpendapat bahwa setiap orang memiliki hak yang sama dengan kebebasan masing-masing. ${ }^{14}$

Pernyataan tersebut mengarah pada pendapat Satjipto Rahardjo yang mengatakan hubungan antara hukum dan keadilan yaitu sebagai dua hal yang tidak bisa dipisahkan, keadilan tidak hanya sebatas membahas tentang sesuatu yang formal semata melainkan sebagai bagian ekspresi cita-cita masyarakat, secara garis besar atau komprehensif. ${ }^{15}$ Keadilan berbeda dengan penyamarataan ataupun memperoleh bagian yang sama. ${ }^{16}$ Indonesia sebagai negara hukum semestinya dapat memberikan keadilan dalam hal pelayanan publik kepada setiap warga negaranya tanpa memandang suatu kelompok ataupun golongan tertentu. Hal tersebut tertuang dalam Undang-Undang Dasar Republik Indonesia 1945 (UUD NRI 1945) di Pasal 28D ayat (1) ${ }^{17}$.

Jika diperhatikan, dalam penerapan PP 24/2018 yang membuat OSS dengan tujuan untuk mempermudah para pelaku usaha dalam mengurus segala perizinannya, sangat patut dipertanyakan apakah sistem tersebut dapat digapai dan digunakan dengan mudah oleh seluruh masyarakat Indonesia. OSS yang perlu diakses menggunakan computer atau gadget dan tersambung internet menyulitkan masyarakat Indonesia yang berada jauh dari jangkauan internet dan memiliki keterbatasan dalam pengoperasiannya. ${ }^{18}$ Padahal keadilan dalam pelayanan publik tidak dapat diukur hanya dengan bagaimana sistem tersebut mudah dan cepat, tetapi bagaimana cara membuat sistem yang dapat menggapai seluruh kalangan masyarakat.

\section{Substansi Hukum}

Menurut Friedman yang dimaksud dengan substansi hukum ialah ciptaan dari struktur hukum, baik peraturan yang dibuat melalui mekanisme struktur formal maupun peraturan yang lahir dari suatu kebiasaan. ${ }^{19}$ Maka, dapat dipahami bahwa substansi hukum meliputi peraturan perundang-undangan yang berlaku yang memiliki

13 Shidarta Dardji Darmohardjo. (2006). Pokok-Pokok Filsafat Hukum: Apa dan Bagaimana Filsafat Hukum Indonesia. Jakarta: Gramedia Pustaka Utama.

14 Rawls. John. (2006). 'Teori Keadilan: Dasar-Dasar Filsafat Politik untuk Mewujudkan Kesejahteraan Sosial dalam Negara', in A Theory of Justice, ed. Uzair Fauzan and Heru Prasetyo. Yogyakarta: Pustaka Pelajar. h. 502.

${ }^{15}$ Satjipto Rahardjo. (2006). Hukum dalam Jagad Ketertiban. Semarang: Universitas Diponegoro, 2006. ${ }^{16}$ Shidarta. (2006). Moralitas Profesi Hukum Suatu Tawaran Kerangka Berfikir. Bandung: PT. Revika Aditama.

17 Pasal 28D ayat (1) UUD NRI 1945 “Setiap orang berhak atas pengakuan, jaminan, perlindungan, dan kepastian hukum yang adil serta perlakuan yang sama dihadapan hukum".

18 Putri Pradnyawidya Sari. (2018). ‘Pemanfaatan Teknologi Digital Sebagai Percepatan Berusaha Oleh Ekonomi Kreatif (Utilization of Digital Technology As a Acceleration of Trying By the Creative Economy)', Jurnal Komunikasi, Media dan Informatika 7, No. 3: 135-44.

${ }^{19}$ H. Cahyono. (2019). Model Mediasi Penal dalam Penanggulangan Konflik Kekerasan. Yogyakarta. 
kekuatan untuk mengikat dan menjadi sebuah panduan untuk aparat penegak hukum.

Substansi hukum yang terkandung dalam pengurusan perizinan berusaha di OSS ini terdapat dalam Pasal 20 PP 24/2018 yang mana dalam kurung waktu 1 (satu) hari saja Izin Usaha langsung dapat terbit. Setelah Izin Usaha terbit, pelaku usaha tidak lepas begitu saja dari tanggung jawabnya. Izin Usaha yang diterbitkan oleh OSS merupakan sebuah langkah awal untuk mendapatkan Izin Lokasi/Izin Lokasi Perairan, Izin Lingkungan dan/atau Izin Mendirikan Bangunan (IMB) menurut komitmen ${ }^{20}$ bagi para pelaku usaha yang membutuhkan prasarana dalam melaksanakan usahanya.

Komitmen inilah yang menjadi "hutang" bagi para pelaku usaha. Secara tidak langsung, dengan bermodalkan Izin Usaha dan/atau Izin Lingkungan dan/ataupun IMB untuk berkomitmen bagi pelaku usaha dapat memulai pembangunan prasarana usahanya. Bahkan untuk usaha yang berada di dalam suatu kawasan tidak dipersyaratkan memiliki Izin Lingkunan maupun IMB untuk memulai pembangunan ${ }^{21}$ dan hanya cukup menyusun RKL-RPL rinci berdasarkan RKL-RPL kawasan. ${ }^{22}$ Akan tetapi, pelaku usaha harus terlebih dahulu menyelesaikan analisis dampak lingkungan (Amdal) dan/atau rencana teknis bangunan gedung. ${ }^{23}$

Melihat penjelasan di paragraf sebelumnya sangat terlihat bahwa peraturan PP 24/2018 lebih condong memberi kemudahan kepada para pelaku usaha bermodal besar. Memang ada pengecualian Izin Lokasi Perairan dan Izin Lingkungan untuk para pelaku usaha mikro, kecil dan menengah (UMKM), ${ }^{24}$ akan tetapi pada segi penerapan OSS tidak semua pelaku usaha mikro mengerti dan dapat menjalankan permohonan berusaha di sistem tersebut. Hal serupa pun diungkapkan oleh pelaku UMKM, Alven Stony, yang mana para pelaku UMKM terkadang harus mempersiapkan biaya tambahan untuk mengelola izin di OSS dikarenakan pelaku UMKM tersebut gagap teknologi (gaptek).25

Selain itu, kendala terhadap permohonan UMKM dalam OSS kerap muncul pada Klasifikasi Baku Lapangan Usaha Indonesia (KBLI) yang tidak sinkron melalui kode data yang berada di Pengesahan AHU Kemenkumham. Akibatnya permohonan di submit langsung ditolak. Petugas biasanya menyarankan kembali ke notaris untuk merubah akta yang pastinya mengeluarkan biaya lebih untuk pengurusan akta tersebut. ${ }^{26}$

Jika dibandingkan dengan Undang-Undang Nomor 25 Tahun 2009 tentang Pelayanan Publik mengenai penerapan OSS ini, tidaklah sesuai yang diharapkan. Pasal 3 huruf b UU 25/2009 menyatakan “Tujuan undang-undang tentang pelayanan publik

\footnotetext{
${ }^{20}$ Pasal 32 ayat (2) PP 24/2018

${ }^{21}$ Pasal 35 ayat (1) dan Pasal 36 PP 24/ 2018

22 Pasal 35 ayat (2) PP 24/2018

${ }^{23}$ Pasal 38 ayat (2) PP 24/2018

24 Pasal 34 huruf d dan Pasal 35 ayat (1) huruf b PP 24/2018

25 Alven Stony, 'Program Afirmasi UMKM, Solusi Bagi Jeritan UMKM', Kompas, 2019, https://www.kompasiana.com/alvenstony0615/5dacf550097f367d2c413522/program-afirmasiumkm-solusi-bagi-jeritan-umkm?page=all.

${ }^{26}$ Ibid.
} 
adalah terwujudnya sistem penyelenggaraan pelayanan publik yang layak sesuai dengan asasasas umum pemerintahan dan korporasi yang baik". Penerapan OSS atas dasar pasal tersebut memang layak, tetapi hanya kepada segelintir orang yang mengerti teknologi. Pelaku UMKM yang mayoritas tidak mengerti dan gaptek tentunya merasa kurang adil karena ketidaktahuannya tersebut. Padahal hakekat hukum diharapkan dapat membawa aturan yang adil pada kalangan masyarakat (rapport du droit, inbreng van recht). ${ }^{27}$

\section{Struktur Hukum}

Struktur hukum (legal structure) merupakan sesuatu yang berkaitan dengan kelembagaan pelaksana hukum, kewenangan lembaga dan personil (aparat penegak hukum).28 Struktur hukum sendiri mempunyai pengaruh yang kuat terhadap unsur budaya hukum. Struktur hukum yang tidak dapat memobilisasi sistem hukum akan menciptakan ketidakpatuhan (disobedience) terhadap hukum itu sendiri. Maka, apabila struktur hukum yang menyelewengkan hukum akan menimbulkan budaya penyalahgunaan hukum. ${ }^{29}$

Mengenai struktur hukum menurut pokok pembahasan diatas, PP 24/2018 merupakan sebuah aturan penguat Peraturan Presiden Nomor 91 Tahun 2017 tentang Percepatan Pelaksanaan Berusaha dimana didalamnya mengatur mengenai penerapan Sistem Perizinan Berusaha Terintegrasi secara elektronik atau OSS. 30 Hal demikian serupa dengan pemikiran Hans Kelsen yang menyatakan bahwa penyajian hukum secara statis, konstitusi menjadi norma yang lebih tinggi merupakan diproyeksikan sebagai bagian dari norma yang lebih rendah. ${ }^{31}$

OSS sebagai sebuah produk dari peraturan PP 24/2018 pastinya akan bersinggungan dengan peraturan yang lebih tinggi atau setara, yaitu undang-undang dan/atau peraturan pemerintah dalam penerapannya. Dalam hal penerbitan Izin Lingkungan oleh OSS sebagaimana diatur dalam PP 24/2018 tentunya menjadi perdebatan banyak kalangan. Dikarenakan penerbitan Izin Lingkungan oleh OSS bertolak belakang sebagaimana yang telah mengatur pada Peraturan Pemerintah Nomor 27 Tahun 2012 tentang Izin Lingkungan. Izin Lingkungan dalam PP 27/2012 dapat dikeluarkan setelah melakukan kategorisasi dan evaluasi Amdal dan UKL-UPL. ${ }^{32}$ Sedangkan Izin Lingkungan yang dikeluarkan OSS dapat terbit setelah adanya Izin Usaha walaupun dengan status komitmen.

Ahli Lingkungan Hidup dan Kehutanan, Hariadi Kartodiharjo menerangi bahwa adanya PP 24/2018 ini justru melemahkan posisi Amdal dan menjadi tidak strategis

\footnotetext{
${ }^{27}$ Theo Huijbers. (1995). Filsafat Hukum. Sleman: Kanisius.

${ }^{28}$ Lawrence M. Friedman. (2001). Hukum Amerika: Sebuah Pengantar, ed. Wisnu Basuki. Jakarta: Tatanusa.

${ }^{29}$ Lutfil Ansori, 'Reformasi Penegakan Hukum Perspektif Hukum Progresif', Jurnal Yuridis 4, no. 2 (2018): 148, https:// doi.org/10.35586/.v4i2.244.

${ }^{30}$ Pasal 2 ayat (1) huruf b nomor 2 Perpres No.91 Tahun 2017

31 Jimly Asshiddiqie and Ali Safa'at. (2006). Teori Hans Kelsen tentang Hukum. Jakarta: Sekretariat Jenderal \& Kepaniteraan MK RI.

32 Pasal 2 ayat (2) PP 27/2012
} 
yang mana selama ini berperan selaku pengambil keputusan. Ia pun menambahkan bahwa PP 24/2018 bertentangangan dengan Undang-Undang Nomor 32 Tahun 2009 tentang Perlindungan dan Pengelolaan Lingkungan Hidup (UU PPLH) yang memperkuat posisi Amdal. ${ }^{33}$

Hal senada pun diungkapkan oleh Direktur Eksekutif Nasional Walhi Nur Hidayati menilai PP No. 24 Tahun 2018 "menabrak" banyak aturan salah satunya UU PPLH. Menurutnya Pemerintah harus memperhatikan lingkungan hidup sebelum menerbitkan kebijakan karena bencana ekologis dan kerusakan lingkungan terus meningkat. Amdal dan izin lingkungan harus menjadi syarat utama yang harus dipenuhi sebelum pemerintah menerbitkan izin bagi pelaku usaha. ${ }^{34}$ Dia pun menambahkan bahwa Amdal dan izin lingkungan jangan hanya dijadikan sekedar formalitas, tetapi harus menjadi syarat utama.

Suharjo menilai dibentuknya hukum ialah untuk memberi perlindungan bagi manusia secara pasif ataupun aktif. Secara pasif bermakna dilakukan melalui cara melakukan suatu upaya pencegahan atas percobaan penyalahgunaan hak atau sikap sewenang-wenang yang ditujukan kepada seseorang ataupun sekelompok orang. Akan tetapi, secara aktif berarti melakukan suatu usaha guna membuat situasi sosial yang manusiawi dan adil. Sama halnya dalam pembentukan dan penerapan PP 24/2018 tidak dapat mengesampingkan masyarakat, seperti adagium ubi societas ibi ius (dimana ada masyarakat disitu ada hukum). ${ }^{35}$

\section{Budaya Hukum}

Budaya hukum sebagai suasana pikiran sosial dan kekuatan sosial yang menentukan bagaimana hukum digunakan, dihindari, atau disalahgunakan. ${ }^{36}$ Sebenarnya dengan terbit dan berlakunya PP 24/2018 membuat suatu kegiatan baru di seluruh kalangan masyarakat yang kemudian akan menjadikan sebuah budaya dalam kegiatan berusaha. Akan tetapi, penerapan ini seakan-akan dipaksakan berlaku sesaat peraturan tersebut diundangkan. ${ }^{37}$

Tidak adanya masa transisi terhadap suatu sistem hukum baru dapat menimbulkan "kekagetan" dalam hukum itu sendiri. Kegiatan yang sebelumnya sudah terbentuk dan berjalan sedemikian rupa, kemudian berubah secara cepat tanpa adanya sosialisasi yang masif dan tanpa memberikan kesempatan kepada masyarakat / pelaku usaha untuk menyiapkan segala sesuatu yang berhubungan dengan izin. "Kekagetan" itu pun terjadi pada saat 1 (satu) bulan berlakunya OSS.

33 PERKHAPPI, 'PP OSS Dinilai Lemahkan Posisi Wajib AMDA', 2019, https://www.perkhappi.or.id/berita-dan-kegiatan/pp-oss-dinilai-lemahkan-posisi-wajib-amdal/. ${ }^{34}$ Rizki Febianto, 'Anggap Kebijakan Ngawur, Aktivis Lingkungan Gugat PP OSS', Alinea, 2019, https:// www.alinea.id/ nasional/anggap-kebijakan-ngawur-aktivis-lingkungan-gugat-pp-ossb1Xm19mZO.

${ }^{35}$ Muhtarom. (2015). 'Pengaruh Budaya Hukum Terhadap Kepatuhan Hukum dalam Masyarakat', SUHUF 27, No. 2: 124-25.

36 Satjipto Rahardjo. (1986). 'Etika, Budaya, Dan Hukum', Jurnal Hukum \& Pembangunan 16, No. 6: 549-56, https://doi.org/10.21143/jhp.vol16.no6.1229.

37 Pasal 107 PP 24/2018 
OSS yang pada awalnya berada dibawah pengendalian Kementerian Perekonomian membuka OSS Lounge di salah satu Gedung Kementerian Perekonomian disesaki oleh para pelaku usaha. Banyaknya para pelaku usaha yang datang untuk berkonsultasi dan merevisi data- data atas kesalahan input pada OSS membuat para pegawai ditempat tersebut kewalahan. Sebelum adanya pembatasan nomor antrian sampai dengan nomor 300, konsultasi tersebut bisa sampai jam 23.00 WIB. ${ }^{38}$

Bahkan ada seorang pelaku usaha yang sudah 6 (enam) kali berkonsultasi karena izin usahanya tertahan yang diakibatkan belum terintegrasinya OSS dengan K/L. ${ }^{39}$ Peristiwa "kekagetan" hukum ini menyebabkan kekacauan yang terjadi dalam masyarakat. Kekacauan inilah yang menjadi tanggung jawab pemerintah dimasa depan yang mana harus memulihkan atau mengembalikan ketertiban masyarakat dan para pelaku usaha dalam berusaha di Indonesia seperti asas restitution in integrum.

\section{B. Kepastian Hukum PP 24 / 2018}

Kepastian hukum sebagai probabilitas yang mana suatu situasi tertentu, salah satunya tersedia aturan-aturan hukum yang jelas (clear), konsisten (consistent), dan diperoleh (accessible), diterbitkan dan diakui. ${ }^{40}$ Disisi lain, kepastian hukum dipahami sebagai suatu aturan-aturan yang maknanya umum menjadi sebuah arahan bagi individu ketika bertingkah laku di dalam masyarakat, baik dalam hubungan dengan sesama individu ataupun dalam hubungannya dengan masyarakat. Melalui aturan tersebut pula akan menimbulkan kepastian hukum. ${ }^{41}$ Kejelasan dan ketegasan tersebut menandakan bahwa adanya suatu hal yang sudah pasti dan tidak dapat di multi tafsirkan. ${ }^{42}$

Kepastian hukum sejatinya sudah yang terkandung pada Pasal 28D ayat (1) UUD 1945 seperti yang telah disebutkan dalam pembahasan sebelumnya dimana setiap warga negara berhak atas kepastian hukum serta perlakuan yang sama dihadapan hukum. Namun, kenyataan di lapangan masih sering ditemukan tumpang tindihnya aturan hukum yang menyebabkan ketidak pastian terhadap suatu norma hukum. Dalam beberapa tahun terakhir ini ketidak pastian hukum sering terjadi pada bidang perizinan berusaha, tepatnya setelah berlakunya PP 24/2018 dengan OSS.

\section{Substansi Hukum}

OSS sebagai implementasi PP 24/2018 digadang-gadang akan mempermudah praktik perizinan berusaha dikalangan masyarakat maupun investor. Mudahnya mengakses dan melakukan permohonan berusaha merupakan keunggulan dari sistem ini. Namun, produk perizinan yang dihasilkan dari OSS masih menjadi perdebatan dikalangan para pengamat karena dinilai melangkahi suatu prosedur ceklis yang seharusnya dipenuhi terlebih dahulu sebelum dikeluarkannya izin.

38 Rinaldi Mohammad Azka. (2018). 'Usahaku Tertahan Perizinan', Bisnis Indonesia, https://koran.bisnis.com/read/20180814/433/827566/1-bulan-online-single-submissionusahaku-tertahan-perizinan.

${ }^{39}$ Ibid.

40 Soeroso. (2011). Pengantar Ilmu Hukum. Jakarta: Sinar Grafika.

${ }^{41}$ Peter Mahmud Marzuki. (2008). Pengantar Ilmu Hukum. Jakarta: Kencana.

42 Ibid. 
Memang benar dalam suatu persetujuan terlebih dahulu harus memenuhi suatu persyaratan yang ditentukan, akan tetapi dalam PP 24/2018 berbanding tebalik dimana izin terlebih dahulu diberikan kemudian terdapat komitmen yang merupakan pernyataan para pelaku usaha untuk memenuhi persyaratan dari Izin Usaha dan/atau Izin Komersial atau Operasional.43

Atas dasar komitmen tersebut, secara tidak langsung pelaku usaha memiliki hutang kepada pemerintah. Pasal 40 PP 24/2018 menerangkan bahwa Izin Usaha yang diberikan oleh OSS dapat dibatalkan begitu saja apabila pelaku usaha belum bisa menyelesaikan pemenuhan komitmen sebagaimana yang dimaksud pada Pasal 32 dan/atau Izin Komersial atau Operasional sebagaimana dimaksud dalam Pasal 39. Dalam pemenuhan komitmen, para pelaku usaha rata-rata diberikan waktu 10 (sepuluh) sampai dengan 30 (tiga puluh) hari untuk menyelesaikan komitmennya dengan melaporkan kepada lembaga atau dinas terkait. Anggap saja pemenuhan komitmen dalam Penyusunan dokumen Amdal diberikan waktu paling lama 30 (tiga puluh) hari kerja sejak OSS menerbitkan Izin Lingkungan. ${ }^{44}$

Padahal terkandung pada Pasal 30 ayat (3) Peraturan Pemerintah 27 Tahun 1999 tentang Analisis Mengenai Dampak Lingkungan Hidup (PP 27/1999) waktu 30 (tiga puluh) hari kerja merupakan jangka waktu untuk warga masyarakat yang berkepentingan atau terkena dampak suatu usaha memberikan atau mengajukan saran, pendapat dan tanggapan tentang akan dilaksanakannya rencana usaha dan/atau kegiatan. Sebelumnya terdapat peniliaian terhadap kerangka acuan Amdal oleh instansi yang bertanggung jawab selambat-lambatnya 75 (tujuh puluh lima) hari kerja. ${ }^{45}$ Dan sesudahnya, instansi diberi waktu selambat-lambatnya 75 (tujuh puluh lima) hari kerja sejak diterimanya dokumen analisis dampak lingkungan, rencana pengelolaan lingkungan hidup, dan rencana pemantauan lingkungan hidup untuk menerbitkan keputusan kelayakan lingkungan hidup suatu usaha atau kegiatan. ${ }^{46}$

Jika diakumulasikan waktu dari awal penyusunan kerangka acuan amdal sampai dengan keputusan instasi layak atau tidaknya suatu kegiatan usaha bisa lebih dari 180 hari atau 9 (sembilan) bulan lamanya. Sedangkan waktu yang diberikan PP 24/2018 untuk menyelesaikan komitmen adalah 30 (tiga puluh) hari kerja yang mana waktu tersebut sangat pendek dan riskan terhadap penyimpangan hasil Amdal yang tidak akurat dan akan berdampak pada lingkungan masyarakat. Ketidakjelasan inilah yang menjadi permasalahan dalam penerapan OSS. Tumpang tindih dan tidak adanya sinkronisasi peraturan satu dengan lainnya menyebabkan tidak adanya kepastian hukum seperti menggambarkan bahwa belum terdapa hukum yang mengatur hal tersebut (ubi jus incertum, ibi jus nullum).

Sementara itu, jika melihat pendapat Utrecht bahwa kepastian hukum meliputi dua pemahaman, yakni: (1) adanya aturan yang sifatnya umum membuat individu

${ }^{43}$ Pasal 1 Nomor 10 PP 24/2018

${ }^{44}$ Pasal 42 ayat (1) PP 24/2018

45 Pasal 16 ayat (2) PP 27/1999

46 Pasal 20 aya (1) PP 27/1999 
mengetahui perbuatan apa yang boleh atau tidak boleh dilakukan; dan (2) berupa keamanan hukum bagi individu dari kesewenangan pemerintah akibat aturan yang bersifat umum itu individu dapat mengetahui apa saja yang boleh dibebankan ataupun dilakukan oleh negara terhadap individu. ${ }^{47} \mathrm{Hal}$ tersebut mengartikan bahwa dengan permasalahan OSS mengenai ketidakpastian hukumnya terlihat bahwa tidak adanya keamanan hukum bagi setiap warga negara akibat kesewenangan pemerintah pada penerapan peraturan.

\section{Struktur Hukum}

Struktur hukum sebagai suatu konteks bentuk yang konsisten dari sistem hukum untuk mengawasi proses tetap berada di dalam batas-batasnya. ${ }^{48}$ Dalam kaitannya dengan PP 24/2018 bahwa sebagai pedoman berlakunya OSS dapat dikatakan bagian dari UU 25/2009 yang merupakan peraturan tertinggi yang mengatur mengenai ketentuan pelayanan publik. Maksud dan tujuan dari UU 25/2009, yaitu dapat memberikan kepastian hukum bagi hubungan antara masyarakat dan penyelenggara dalam pelayanan publik. ${ }^{49}$

OSS yang tergolong dalam penyelenggara pelayanan publik dan bagian dari pemerintahan mengharuskan memberikan kepastian hukum kepada masyarakat dalam menjalankan pelayanan administratif khususnya perizinan berusaha. ${ }^{50}$ Pelayanan administratif yang dilakukan oleh OSS juga mewajibkan bahwa suatu tindakan administratif harus berlandaskan peraturan perundang-undangan yang berlaku. ${ }^{51}$

Pelayanan administratif sebagai suatu tindakan administratif juga diatur oleh Undang-Undang 30 Tahun 2014 tentang Administrasi Pemerintahan (UU 30/2014) sebagaimana diatur dalam Pasal 1 nomor 8 yang menjelaskan bahwa tindakan administrasi pemerintahan merupakan perbuatan Pejabat Pemerintahan atau penyelenggara negara lainnya bagi yang melakukan dan/atau tidak melakukan tindakan konkrit pada rangka penyelenggaraan pemerintahan.

OSS sebagai sistem yang dikelola oleh Badan Koordinasi Penanaman Modal (BKPM) yang mempunyai kewenangan dalam memberikan izin berusaha kepada setiap pelaku usaha patutnya berpedoman pada undang-undang yang mengatur terkait izin yang dikeluarkan, seperti AMDAL berpedoman pada PP 27/1999 dan Izin Lingkungan berpedoman pada Undang- Undang Nomor 32 Tahun 2009 tentang Perlindungan dan Pengelolaan Lingkungan Hidup ataupun peraturan pelaksanaannya PP 27/2012. Hal tersebut kembali ditegaskan dalam Pasal 39 ayat (1) dan (2) UU 30/2014.

Melihat uraian di atas dapat disimpulkan bahwa untuk menjamin suatu kepastian hukum harus berdasarkan norma-norma hukum yang telah diatur dan berlaku.

${ }^{47}$ Syahrani, Rangkuman Intisari Ilmu Hukum. Op. Cit. h. 23

48 Ismansyah. (2010). ‘Permasalah Hukum dalam Pengembangan Ilmu Hukum di Indonesia (Pentingnya Reformasi Hukum Terkait dengan Permasalahan Hukum)', Jurnal Demokrasi 9, No. 1.

${ }^{49}$ Pasal 2 UU 25/2009

50 Pasal 3 huruf d UU 25/2009

51 Pasal 5 ayat (7) UU 25/2009 
Namun, dalam penerapan OSS dan/atau PP 24/2018 sebagai bentuk dari pelayanan pubkik masih ditemukan norma-norma hukum yang menyimpang dari peraturan yang mengatur secara khusus tentang pelayanan publik dan administrasi pemerintahan (izin). Selain itu, PP 24/2018 sebagai aturan pelaksaan pelayanan publik seharusnya berpedoman pada UU 25/2009 dan UU 20/2014. Jika dilihat pembukaan PP 24/2018 dalam hal "Menimbang" dan "Mengingat" tidak terdapat kedua UU tersebut, bahkan hanya terdapat Undang- Undang 25 Tahun 2007 tentang Penanaman Modal dan Undang-Undang Nomor 9 Tahun 2015 tentang Perubahan Kedua Atas Undang-Undang Nomor 23 Tahun 2014 tentang Pemerintahan Daerah.

Benar memang dibentuknya PP 24/2018 bertujuan untuk memudahkan penanaman modal atau berusaha dan terintegrasinya antara sistem pusat dengan daerah. Akan tetapi di sisi lain PP 24/2018 juga tergolong ke dalam suatu peraturan yang mengatur bagaimana proses suatu perizinan itu berjalan yang ujung-ujungnya berakhir pada pelayanan publik dan menghasilkan suatu produk hukum perizinan yang tergolong ke dalam administrasi pemerintahan. Tidak adanya UU 25/2009 dan UU 20/2014 dalam pembukaan sebagai dasar penyusunan PP 24/2018 dapat dikatakan bahwa dalam penyusunan peraturan pelaksaan tersebut mengesampingkan asas lex specialis derogate legi generalis yang dapat mempengaruhi kepastian hukum atas produk hukum yang diterbitkan OSS.

\section{Budaya Hukum}

Perubahan kebiasaan masyarakat pastinya akan terjadi pasca berlakunya PP 24/2018. Budaya konvensional yang datang ke suatu tempat dengan membawa berkas fotokopi persyaratan dan surat permohonan merupakan cara lama yang 5 (lima) sampai 10 (sepuluh) tahun kemudian akan hilang. Sedangkan OSS sebagai salah satu cita-cita dalam mewujudkan budaya baru yang paperless dan mudah masih mengalami kendala yang kadang kala menyulitkan penggunanya untuk mendapatkan kepastian hukum secara legal.

Kendala ataupun hambatan pasti terjadi dalam setiap adanya perubahan kebiasaan dalam masyarakat. Dalam membentuk suatu budaya hukum yang sehat dinilai paling sulit dengan alasan memerlukan jangka waktu yang relatif cukup panjang. Hal tersebut dapat terjadi akibat budaya yang berkaitan dengan nilai-nilai. Maka, apa yang berkaitan dengan nilai, pasti membutuhkan sebuah proses internalisasi agar nilai-nilai itu tidak hanya sekadar dimengerti, akan tetapi juga dipraktikkan pada kehidupan sehari-hari. 52

Menurut pendapat Soerjono Soekanto, terdapat empat tahapan suatu masyarakat untuk bisa memiliki sebuah kesadaran hukum yang baik, yakni: (1)pengetahuan hukum; (2) pemahaman hukum; (3) sikap hukum; dan (4) pola perilaku hukum. ${ }^{53}$ Diterapkannya OSS merupakan salah satu cara merubah kebiasaan masyarakat

52 Dardji Darmohardjo, Pokok-Pokok Filsafat Hukum: Apa dan Bagaimana Filsafat Hukum Indonesia. Loc.Cit.

${ }^{53}$ Soerjono Soekanto. (1982). Kesadaran Hukum dan Kepatuhan Hukum. Jakarta: Rajawali Press. h. 140. 
dalam berpraktik hukum yang sehat. Hal ini bertolak belakang dengan asas het recht hinkt achter de feiten aan yang mana hukum selalu ketinggalan dari akibatnya. Kebiasaan lama yang pada praktiknya membuat hukum itu seakan-akan bisa "dibeli" menyebabkan hilangnya kepastian hukum terhadap hukum itu sendiri. Kekeliruan pemahaman masyarakat terhadap hukum juga menjadi salah satu indikator maraknya "jual-beli" yang dilakukan oleh oknum yang memiliki kewenangan. Maka dari itu, dengan diterbitkan dan berlakunya OSS diharapkan masyarakat dapat mengerti dan memahami sebuah proses hukum secara sehat dan langsung.

\section{Kemanfaatan Hukum Penerapan OSS}

Menurut Sudikno Mertokusumo yang dimaksud dengan kemanfaatan hukum ialah asasnya setelah dipertimbangkan, keabsahan (rechmatigheid) tindakannya, kemudian dipertimbangkan manfaatnya (doelmatigheid). ${ }^{54}$ Disisi lain, Jeremy Bentham menjelaskan hukum yang benar apabila dapat memberikan suatu kebahagiaan bagi sebagian terbesar dari masyarakat dimana hukum itu berada (the greatest happiness of the greatest number). Nilai kemanfaatan yang terdapat pada individu yang melahirkan kebahagiaan individual (happiness of individual) maupun masyarakat (happiness of community). 55

Tujuan hukum sendiri diharapkan dapat memberikan kemanfaatan serta kebahagiaan bagi masyarakat sebanyak-banyaknya dan sarana untuk bisa mencapai suatu tujuan yang telah ditetapkan. ${ }^{56}$ Berdasarkan teori kemanfaatan, nota kesepahaman dan perjanjian yang tertuang di dalam Peraturan Presiden tersebut tidak hanya memberikan kemudahan akan tetapi memberikan manfaat dalam membuat keputusan dan memberikan nilai tambah pada transaksi yang dibuat.

\section{Substansi Hukum}

OSS sebagai salah satu sistem pelayanan publik sudah sepatutnya memberikan manfaat kepada semua penggunanya. Penerapan komitmen dalam mengeluarkan izin usaha merupakan salah satu manfaat yang dapat dirasakan oleh para pelaku usaha. Oleh karena izin usaha, para pelaku usaha dapat secara paralel atau bersamaan mengurus izin operasional lainnya sambil memenuhi persyaratan pemenuhan komitmen izin usaha tersebut. ${ }^{57}$

Dalam rangka pelaksanaan penerbitan Izin Usaha dengan komitmen selain diatur dalam Pasal 32 PP 24/2018, juga diatur dalam Perpres 91/2017 salah satunya pada Pasal 23 ayat (3) yang mana pelaku usaha dapat menerima izin dengan hanya berdasarkan mengisi dan menandatangani formulir permohonan sebagai bentuk pemenuhan persyaratan (checklist) dengan kewajiban dan jangka waktu penyempurnaan persyaratan yang harus dipenuhi.

\footnotetext{
${ }^{54}$ Sudikno Mertokusumo. (2011). Teori Hukum, 1st ed. Yogyakarta: Universitas Atma Jaya.

55 Jeremy Bentham. (2000). An Introduction to the Principles of Morals and Legislation. Kitchener: Batoche Books.

56 Darji Darmodihardjo. (2011). Filsafat Hukum: Dari Klasik Sampai Postmodernisme. Yogyakarta: Universitas Atma Jaya.

57 Suhartoyo Suhartoyo. (2019). 'Implementasi Fungsi Pelayanan Publik dalam Pelayanan Terpadu Satu Pintu (PTSP)', Administrative Law and Governance Journal 2, No. 1: 143-54, https://doi.org/10.14710/alj.v2i1.143-154.
} 
Kemanfaatan dari adanya OSS bagi para pelaku usaha memang begitu terasa karena dilaksanakan dengan sistem berbasis elektronik, online dan mengurangi praktik- praktik lama secara konvensional yang riskan terjadinya "transaksi" oleh oknum birokrat diluar peraturan perundang-undangan yang berlaku. Para pelaku usaha sepatutnya berbahagia dengan adanya OSS yang membuat segala sesuatu dalam perizinan menjadi mudah dalam penerbitan izin usaha dengan bermodalkan "hutang" komitmen.

Akan tetapi, dalam rangka melaksanakan konstruksi para pelaku usaha dalam kurung waktu 90 hari sejak melakukan permohonan / register harus memulai proses kontruksi58 dan wajib menyelesaikan "hutang" persyaratn seperti Upaya Pengelolaan Lingkungan Hidup dan Upaya Pemantauan Lingkungan Hidup (UKL-UPL), sertifikat tanah, IMB, Izin Usaha Industri atau Tanda Daftar Usaha Pariwisata sebagaimana diatur dalam Pasal 7 ayat (2) huruf a Perpres 91/2017.

Apabila pelaku usaha tidak dapat menyelesaikan "hutang" komitmen dalam waktu yang ditentukan dan juga belum memulai proses kontruksi, PTSP Pusat, DPMPTSP Provinsi atau Kabupaten/Kota memiliki kewenangan untuk memberikan teguran tertulis, memberikan penangguhan perizinan berusaha, memberikan perpanjangan waktu untuk memenuhi persyaratan yang belum dipenuhi, memberhentikan kegiatan sementara, dan/atau mencabut Izin Usaha sementara berdasarkan komitmen. ${ }^{59} \mathrm{Hal}$ ini mengartikan bahwa jika sampai terjadinya pencabutan izin usaha, pelaku usaha tidak bisa melanjutkan usahanya walaupun proses pemenuhan komitmennya sudah setengah jalan.

Hal tersebut sepatutnya memang perlu dilakukan oleh negara terhadap para pelaku usaha yang tidak bisa memenuhi janjinya atau membayar "hutang" nya demi menjaga dan melindung (to provide security) masyarakat warga negara yang terkena dampak dari usaha tersebut dan juga melindungi negara dari kesewenang-wenangan pihak tertentu yang melanggar aturan norma hukum. ${ }^{60}$

Hal ini sejalan dengan konsep "law is a tool of social engineering" yang diungkapkan oleh Roscoe Pound yang mana hukum merupakan institusi terpenting didalam suatu pelaksanaan kontrol sosial. ${ }^{61}$ Menurutnya, kontrol sosial dibutuhkan untuk melestarikan peradaban dengan alasan fungsi utamanya dalam mengendalikan "aspek internal ataupun sifat manusia" yang dianggapnya sangat diperlukan bagi menaklukkan aspek eksternal atau lingkungan fisikal. ${ }^{62}$

\section{Struktur Hukum}

Adanya Perpres 91/2017 merupakan sebuah keuntungan dalam penerapan OSS

\footnotetext{
58 Pasal 25 ayat (7) Perpres 91/2017

${ }^{59}$ Pasal 24 ayat (8) Perpres 91/2017

60 Zainab Ompu Jainah. (2010). Kapita Selekta Hukum Pidana, ed. Intan Nurina Seftiniara. Tangerang: Tira Smart.

${ }^{61}$ Martha Safira. (2017). 'Law as a Tool of Social Engineering', Kodifikasia Jurnal Penelitian Islam 11, No. 1. https://doi.org/10.2991/icsse-17.2018.28.

${ }^{62}$ Lili Rasjidi and Ira Thania Rasjidi. (2007). Dasar-Dasar Filsafat Dan Teori Hukum (Bandung: Citra Aditya Bakti. h. 74.
} 
di Indonesia. Secara hierarki kekuatan hukum perpres memang berada di bawah undang-undang ataupun peraturan pemerintah, tetapi dalam pembentukan peraturan OSS Perpres ini bisa dikatakan menginisiasi diundangkannya PP 24/2018. Sayangnya, dalam pembuatan PP 24/2018 tidak memperhatikan undang-undang yang berkaitan dengan pelayanan public ataupun hal yang berkaitan dengan administrasi pemerintahan. Padahal OSS bisa dikatakan sebagai sistem pelayanan publik yang menghasilkan produk administrasi pemerintahan dan berakibat hukum secara positif atau negatif terhadap para penggunanya.

Jika melihat hierarki diundangkannya PP 24/2018, di masa depan dapat terjadi ketidakpastian hukum yang berujung pada kurang bermanfaatnya undang-undang dikarenakan bersinggungan dan tidak sejalan dengan peraturan perundangundangan terkait yang mengatur secara spesial hal-hal / izin-izin tertentu. Sementara itu, untuk mencapai kemanfaatan yang dirasakan oleh masyarakat warga negara, dalam perundang- undangan minimal adanya kesamaan/persamaan (to attain equity) persepsi antara peratura-peraturan yang saling berkaitan.

Ketidaksinambungan pun dapat terjadi dalam satu tubuh peraturan, misalnya Pasal 24 ayat (7) Perpres 91/2017 dimana menyebutkan “...pelaksanaan kontruksi paling lambat 90 (sembilan puluh hari) sejak diregister sebagaimana dimaksud pada ayat (4)" secara tidak langsung pelaku usaha harus menyelesaikan komitmen yang terdapat dalam ayat (4) seperti UKL-UPL, IMB, dll dalam waktu 90 (sembilan puluh) hari. Sementara itu, pada ayat (11) terkait pemenuhan persyaratan komitmen dilakukan sesuai dengan ketentuan peraturan perundang-undangan. Jika yang dimaksud ketentuan peraturan perundang-undang dari masing-masing peraturan izin pada ayat (2) huruf $a^{63}$, apabila diakumulasikan waktu yang dibutuhkan bisa lebih dari 90 (sembilan puluh) hari.

Atas hal tersebut, kemanfaatan tidak hanya dapat dilihat dari kebahagiaan yang dirasakan oleh masyarakat saja, tetapi juga harus adanya kesinambungan antara peraturan satu dengan peraturan lainnya yang saling berkaitan. Hal demikian harus menjadi dasar dalam pembentukan peraturan perundang-undangan agar terciptanya kepastian hukum yang tentunya berpengaruh pada kepuasan dan kebahagiaan masyarakat warga negara pada suatu aturan hukum.

\section{Budaya Hukum}

Budaya akan tampak hadir atau terlihat ketika mendapatkan suatu aksi dari luar, dengan demikian budaya merupakan suatu reaksi dan respon sosial. Kendati demikian, sejatinya tidak semua budaya lahir secara alami, terdapat dorongan dari luar yang dapat melahirkan atau merubah budaya, salah satu diantaranya ialah hukum. ${ }^{64}$ Menurut teori utilitarianisme, bahwa yang dimaksud dengan adanya

63 ....perizinan dalam rangka konstruksi dan komersial, yang mencakup paling sedikit: 1 . Upaya Pengelolaan Lingkungan Hidup dan Upaya Pemantauan Lingkungan Hidup (UKL-UPL); 2. sertifikat tanah; 3. Teknis bangunan/Izin Mendirikan Bangunan (IMB); dan 4. Izin Usaha Industri (IUI) atau Tanda Daftar Usaha Pariwisata (TDUP).

${ }^{64}$ Satjipto Rahardjo. (1980). Hukum dan Masyarakat. Bandung: Alumni. 
hukum ialah pandangan yang meletakan kemanfaatan sebagai tujuan utama hukum dan adapun ukuran kemanfaatan hukum yakni kebahagian bagi orang-orang yang sebesar-besarnya. ${ }^{65}$

Penerapan OSS dibidang pelayanan publik secara tidak langsung merubah kebiasaan masyarakat yang sudah lama terbentuk dengan kebiasaan fotokopi dan membawa berkas persyaratan ke dinas terkait untuk mendapatkan produk perizinan. Pemberlakuan OSS belum sepenuhnya berhasil dikarenakan tidak semua masyarakat warga negara bisa menggunakannya. Sebagai sistem yang berbasis elektronik dan harus menyambung internet untuk mengaksesnya, tidak semua kalangan bisa dan mengerti cara-cara melakukan permohonan, bahkan untuk daerah yang jauh dari jangkauan internet dengan terpaksa tidak patuh secara hukum.

Akan tetapi, dengan adanya OSS pemerintah sudah mencoba untuk memberi perlindungan (to provide security) kepada masyarakat warga negaranya dengan merubah situasi jadul (jaman dulu) yang sarat dengan "permainan" birokrat menjadi suatu pelayanan publik yang diawasi dan dijalani secara otomatis berdasarkan sistem. Melihat dari manfaatnya sistem OSS ini memang harus banyak pembenahan dan peningkatan ketelitian pada sistem tersebut, tetapi jika sistem OSS sudah sempurna akan terlihat manfaatnya dengan bagaimana hukum membentuk peradaban masyarakat modern seperti asas law is a tool of social engineering yang mana hukum sebagai sebuah kontrol sosial dalam membentuk suatu peradaban atau budaya baru pada masyarakat.

\section{PENUTUP}

Berdasarkan penjelasan dan analisis di atas, Penulis dapat menyimpulkan bahwa dalam penerapan dan berlakunya OSS atas dasar Peraturan Pemerintah Nomor 24 Tahun 2019 tentang Pelayanan Perizinan Berusaha Terintegrasi Secara Elektronik tidak sesuai dengan tujuan hukum. Hal tersebut dikarenakan tidak adanya masa transisi dalam pemberlakuan peraturannya dan memberi kesempatan bagi masyarakat dan/atau pelaku usaha untuk belajar dan menyesuaikan dengan sistem yang benar-benar baru dalam dunia perizinan berusaha. Selain itu, adanya tumpang tindih antara peraturan satu dengan peraturan lainnya yang mana menyebabkan ketidakpastian hukum yang kemudian berpengaruh kepada kemanfaatan hukum itu sendiri. Dengan demikian penerapan OSS atau PP 24/2018 tidak sesuai dengan tujuan hukum.

Yang dapat dilakukan masyarakan warga negara adalah melakukan judicial review dan/atau DPR-RI sebagai badan legislatif melakukan amandemen/perubahan terhadap Peraturan Pemerintah Nomor 24 Tahun 2018 tentang Pelayanan Perizinan Berusaha Terintegrasi Secara Elektronik karena banyaknya tumpang tindih dengan peraturan yang secara khusus sudah mengaturnya sehingga tidak adanya kepastian hukum yang berpengaruh terhadap iklim berusaha di Indonesia.

${ }^{65}$ Darji Darmodihardjo. (1990). 'Filsafat Hukum', in Filsafat Hukum Edisi Lengkap (Dari Klasik Sampai Postmoderenisme). Jakarta: Rajawali Press, h. 111. 


\section{DAFTAR PUSTAKA}

\section{Peraturan Perundang-undangan}

Undang-Undang Nomor 25 Tahun 2009 tentang Pelayanan Publik.

Undang-Undang Nomor 32 Tahun 2009 tentang Perlindungan dan Pengelolaan

Lingkungan Hidup

Undang-Undang Nomor 30 Tahun 2014 tentang Administrasi Pemerintahan.

Peraturan Pemerintah Nomor 27 Tahun 2012 tentang Izin Lingkungan

Peraturan Pemerintah Nomor 24 Tahun 2018 tentang Pelayanan Perizinan Berusaha

Terintegrasi Secara Elektronik

Peraturan Presiden Nomor 91 Tahun 2017 tentang Percepatan Pelaksanaan Berusaha

Buku

Apeldoorn, L.j Van. (2006). Moralitas Profesi Hukum Suatu Tawaran Kerangka Berfikir. Bandung: Revika Aditama.

Asshiddiqie, Jimly, and Ali Safa'at. (2006). Teori Hans Kelsen Tentang Hukum. Jakarta: Sekretariat Jenderal \& Kepaniteraan MK RI.

Atmosudirjo, Prajudi. (2001). Hukum Administrasi Negara. Jakarta: Ghalia Indonesia.

Bentham, Jeremy. (2000). An Introduction to the Principles of Morals and Legislation. Kitchener: Batoche Books.

Cahyono, H. (2019). Model Mediasi Penal dalam Penanggulangan Konflik Kekerasan. Yogyakarta.

Dardji Darmohardjo, Shidarta. (2006). Pokok-Pokok Filsafat Hukum: Apa dan Bagaimana Filsafat Hukum Indonesia. Jakarta: Gramedia Pustaka Utama.

Darmodihardjo, Darji. (2011). Filsafat Hukum: Dari Klasik Sampai Postmodernisme. Yogyakarta: Universitas Atma Jaya.

. (1990). 'Filsafat Hukum'. In Filsafat Hukum Edisi Lengkap (Dari Klasik Sampai Postmoderenisme), 111. Jakarta: Rajawali Press.

Fajar, Mukti, and Yulianto Achmad. (2013). Dualisme Penelitian Hukum Normatif \& Empiris. Yogyakarta: Pustaka Belajar.

Friedman, Lawrence M. (2001). Hukum Amerika: Sebuah Pengantar. Edited by Wisnu Basuki. Jakarta: Tatanusa.

Hasan, Iqbal. (2008). Analisis Data Penelitian Dengan Statistik. Jakarta: Bumi Aksara.

Huijbers, Theo. (1995). Filsafat Hukum. Sleman: Kanisius.

Jainah, Zainab Ompu. (2010). Kapita Selekta Hukum Pidana. Edited by Intan Nurina Seftiniara. Tangerang: Tira Smart.

John, Rawls. (2006). 'Teori Keadilan: Dasar-Dasar Filsafat Politik Untuk Mewujudkan Kesejahteraan Sosial Dalam Negara'. In A Theory of Justice, edited by Uzair Fauzan and Heru Prasetyo, 502. Yogyakarta: Pustaka Pelajar.

Popper, Karl R. (2002). Masyarakat Terbuka dan Musuh-Musuhnya (The Open Society and Its Enemy). Yogyakarta: Pustaka Pelajar.

Marzuki, Peter Mahmud. (2010). Penelitian Hukum. Jakarta: Kencana Prenada. . (2008). Pengantar Ilmu Hukum. Jakarta: Kencana.

Mertokusumo, Sudikno. (2011). Teori Hukum. 1st ed. Yogyakarta: Universitas Atma Jaya.

Rahardjo, Satjipto. (2006). Hukum dalam Jagad Ketertiban. Semarang: Universitas Diponegoro.

Rasjidi, Lili, and Ira Thania Rasjidi. (2007). Dasar-Dasar Filsafat dan Teori Hukum. Bandung: Citra Aditya Bakti.

Saifullah. (2004). Konsep Dasar Metode Penelitian Dalam Proposal Skripsi. Malang: UIN 
Malang.

Shidarta. (2006). Moralitas Profesi Hukum Suatu Tawaran Kerangka Berfikir. Bandung: PT. Revika Aditama.

Soekanto, Soerjono. (1982). Kesadaran Hukum Dan Kepatuhan Hukum. Jakarta: Rajawali Press.

Soekanto, Soerjono, and Sri Mamudji. (2003). Penelitian Hukum Normatif: Suatu Tinjauan Singkat. Jakarta: Raja Grafindo Persada.

Soeroso. (2011). Pengantar Ilmu Hukum. Jakarta: Sinar Grafika.

Suted, Adrian. (2017). Hukum Perizinan dalam Sektor Pelayanan Publik. 1st ed. Jakarta: Sinar Grafika.

Syahrani, Riduan. (1999). Rangkuman Intisari Ilmu Hukum. Bandung: Citra Aditya.

Jurnal

Ansori, Lutfil. (2018). 'Reformasi Penegakan Hukum Perspektif Hukum Progresif'. Jurnal Yuridis 4, No. 2: 148. https:// doi.org/10.35586/.v4i2.244.

Apeldoorn, L.j Van. (2006). Moralitas Profesi Hukum Suatu Tawaran Kerangka Berfikir. Bandung: Revika Aditama.

Arrum, Desi Arianing. (2019). 'Kepastian Hukum Dalam Perizinan Berusaha Terintegrasi Secara Elektronik (Online Single Submission) di Indonesia'. Jurist-Diction 2, No. 5: 1631. https://doi.org/10.20473/jd.v2i5.15222.

Assegaf, Muhammad Iqbal Fitra, Henny Juliani, and Nabiatus Sa'adah. (2019). ‘Pelaksanaan Online Single Submission (OSS) Dalam Rangka Percepatan Perizinan Berusaha Di Dinas Penanaman Modal Dan Pelayanan Terpadu Satu Pintu (DPMPTSP) Jawa Tengah'. Jurnal Hukum Diponegoro 8, No. 2: 1328-42.

Asshiddiqie, Jimly, and Ali Safa'at. (2006). Teori Hans Kelsen tentang Hukum. Jakarta: Sekretariat Jenderal \& Kepaniteraan MK RI.

Atmosudirjo, Prajudi. (2001). Hukum Administrasi Negara. Jakarta: Ghalia Indonesia.

Azka, Rinaldi Mohammad. (2018). 'Usahaku Tertahan Perizinan'. Bisnis Indonesia,. https:// koran.bisnis.com/read/20180814/433/827566/1-bulan-online-singlesubmission-usahaku-tertahan-perizinan.

Bentham, Jeremy. (2000). An Introduction to the Principles of Morals and Legislation. Kitchener: Batoche Books.

Cahyono. (2019). H. Model Mediasi Penal Dalam Penanggulangan Konflik Kekerasan. Yogyakarta.

Dardji Darmohardjo, Shidarta. (2006). Pokok-Pokok Filsafat Hukum: Apa Dan Bagaimana Filsafat Hukum Indonesia. Jakarta: Gramedia Pustaka Utama.

Darmodihardjo, Darji. (2011). Filsafat Hukum: Dari Klasik Sampai Postmodernisme. Yogyakarta: Universitas Atma Jaya.

(1990). 'Filsafat Hukum'. In Filsafat Hukum Edisi Lengkap (Dari

Klasik Sampai Postmoderenisme), 111. Jakarta: Rajawali Press.

Fajar, Mukti, and Yulianto Achmad. (2013). Dualisme Penelitian Hukum Normatif \& Empiris. Yogyakarta: Pustaka Belajar.

Febianto, Rizki. (2019). 'Anggap Kebijakan Ngawur, Aktivis Lingkungan Gugat PP OSS'. Alinea. https://www.alinea.id/nasional/anggap-kebijakan-ngawur-aktivislingkungan-gugat-pp-oss-b1Xm19mZO.

Friedman, Lawrence M. (2001). Hukum Amerika: Sebuah Pengantar. Edited by Wisnu Basuki. Jakarta: Tatanusa.

Gunawan, Arif. (2019). 'Ini Penyebab Peringkat Doing Business Indonesia Mentok Di 73'. CNBC Indonesia. https://www.cnbcindonesia.com/news/20191024225303-4- 
109976/ini-penyebab-peringkat-doing-business-indonesia-mentok-di-73/1.

Hasan, Iqbal. (2008). Analisis Data Penelitian dengan Statistik. Jakarta: Bumi Aksara.

Huijbers, Theo. (1995). Filsafat Hukum. Sleman: Kanisius.

Ismansyah. (2010). 'Permasalah Hukum Dalam Pengembangan Ilmu Hukum di Indonesia

(Pentingnya Reformasi Hukum Terkait Dengan Permasalahan Hukum)’. Jurnal Demokrasi 9, No. 1.

Jainah, Zainab Ompu. (2010). Kapita Selekta Hukum Pidana. Edited by Intan Nurina Seftiniara. Tangerang: Tira Smart.

John, Rawls. (2006). 'Teori Keadilan: Dasar-Dasar Filsafat Politik untuk Mewujudkan Kesejahteraan Sosial dalam Negara'. In A Theory of Justice, edited by Uzair Fauzan and Heru Prasetyo, 502. Yogyakarta: Pustaka Pelajar.

Marzuki, Peter Mahmud. (2010). Penelitian Hukum. Jakarta: Kencana Prenada. . (2008). Pengantar Ilmu Hukum. Jakarta: Kencana.

Meray, Inri Monica Priscila. (2014). 'Implementasi One Stop Servica (OSS) Dan Pelayanan Perizinan Terpadu (BP2T) Kota Manado'. Jurnal Administrasi Publik 1, No. 1: 1-11.

Mertokusumo, Sudikno. (2011). Teori Hukum. 1st ed. Yogyakarta: Universitas Atma Jaya.

Muhtarom. (2015). 'Pengaruh Budaya Hukum Terhadap Kepatuhan Hukum Dalam Masyarakat'. SUHUF 27, No. 2.

PERKHAPPI. (2019). 'PP OSS Dinilai Lemahkan Posisi Wajib AMDA'. https://www.perkhappi.or.id/berita-dan-kegiatan/pp-oss-dinilai-lemahkan-posisiwajib-amdal/.

Popper, Karl R. (2002). Masyarakat Terbuka dan Musuh-Musuhnya (The Open Society and Its Enemy). Yogyakarta: Pustaka Pelajar.

Rahardjo, Satjipto. (1986). 'Etika, Budaya, dan Hukum'. Jurnal Hukum \& Pembangunan 16, No. 6. https:// doi.org/10.21143/jhp.vol16.no6.1229.

Diponegoro.

(2006). Hukum dalam Jagad Ketertiban. Semarang: Universitas

(1980). Hukum dan Masyarakat. Bandung: Alumni.

Rasjidi, Lili, and Ira Thania Rasjidi. (2007). Dasar-Dasar Filsafat dan Teori Hukum. Bandung: Citra Aditya Bakti.

Rizki, Mochamad Januar. (2019). 'Dinilai Tak Maksimal, Aturan OSS Perlu Dievaluasi'. Hukum

Online.

https://www.hukumonline.com/berita/baca/lt5d78d3507a42d/dinilai-takmaksimal-aturan-oss-perlu-dievaluasi/.

Safira, Martha. (2017). 'Law as a Tool of Social Engineering'. Kodifikasia Jurnal Penelitian Islam 11, No. 1. https:// doi.org/10.2991/icsse-17.2018.28.

Saifullah. (2004). Konsep Dasar Metode Penelitian Dalam Proposal Skripsi. Malang: UIN Malang.

Sari, Putri Pradnyawidya. (2018). ‘Pemanfaatan Teknologi Digital Sebagai Percepatan Berusaha Oleh Ekonomi Kreatif (Utilization of Digital Technology As a Acceleration of Trying By the Creative Economy)'. Jurnal Komunikasi, Media dan Informatika 7, No. 3.

Shidarta. (2006). Moralitas Profesi Hukum Suatu Tawaran Kerangka Berfikir. Bandung: PT. Revika Aditama.

Soekanto, Soerjono. (1982). Kesadaran Hukum Dan Kepatuhan Hukum. Jakarta: Rajawali Press.

Soekanto, Soerjono, and Sri Mamudji. (2003). Penelitian Hukum Normatif: Suatu Tinjauan Singkat. Jakarta: Raja Grafindo Persada. 
Soeroso. (2011). Pengantar Ilmu Hukum. Jakarta: Sinar Grafika.

Stony, Alven. (2019). 'Program Afirmasi UMKM, Solusi Bagi Jeritan UMKM'. Kompas. https://www.kompasiana.com/alvenstony0615/5dacf550097f367d2c413522/progra m-afirmasi-umkm-solusi-bagi-jeritan-umkm?page=all.

Suhartoyo, Suhartoyo. (2019). 'Implementasi Fungsi Pelayanan Publik Dalam Pelayanan Terpadu Satu Pintu (PTSP)'. Administrative Law and Governance Journal 2, No. 1. https:// doi.org/10.14710/alj.v2i1.143-154.

Sulardi. (2015). 'Kepastian Hukum, Kemanfaatan, dan Keadilan terhadap Perkara Pidana Anak'. Jurnal Yudisial 9, No. 3.

Suted, Adrian. (2017). Hukum Perizinan dalam Sektor Pelayanan Publik. 1st ed. Jakarta: Sinar Grafika.

Syahrani, Riduan. (1999). Rangkuman Intisari Ilmu Hukum. Bandung: Citra Aditya.

Wijayanta, Tata. (2014). 'Asas Kepastian Hukum, Keadilan Dan Kemanfaatan Dalam Kaitannya Dengan Putusan Kepailitan Pengadilan Niaga'. Jurnal Dinamika Hukum 14, No. 2.

Wirayani, Prima. (2018). 'Ease of Doing Business RI Turun, Ini Penjelasan Bank Dunia'. CNBC Indonesia. https://www.cnbcindonesia.com/news/20181031201049-440020/ease-of-doing-business-ri-turun-ini-penjelasan-bank-dunia.

\section{Artikel Online}

Azka, Rinaldi Mohammad. 'Usahaku Tertahan Perizinan'. Bisnis Indonesia, 2018. https://koran.bisnis.com/read/20180814/433/827566/1-bulan-online-singlesubmission-usahaku-tertahan-perizinan.

Febianto, Rizki. 'Anggap Kebijakan Ngawur, Aktivis Lingkungan Gugat PP OSS'. Alinea, $2019 . \quad$ https://www.alinea.id/nasional/anggap-kebijakan-ngawur-aktivislingkungan-gugat-pp-oss-b1Xm19mZO.

Gunawan, Arif. 'Ini Penyebab Peringkat Doing Business Indonesia Mentok Di 73'. CNBC Indonesia, 2019. https://www.cnbcindonesia.com/news/20191024225303-4109976/ini-penyebab-peringkat-doing-business-indonesia-mentok-di-73/1.

Rizki, Mochamad Januar. ‘Dinilai Tak Maksimal, Aturan OSS Perlu Dievaluasi'. Hukum Online, 2019. https://www.hukumonline.com/berita/baca/lt5d78d3507a42d/dinilai-takmaksimal-aturan-oss-perlu-dievaluasi/.

PERKHAPPI. 'PP OSS Dinilai Lemahkan Posisi Wajib AMDA', 2019. https://www.perkhappi.or.id/berita-dan-kegiatan/pp-oss-dinilai-lemahkan-posisiwajib-amdal/.

Stony, Alven. 'Program Afirmasi UMKM, Solusi Bagi Jeritan UMKM'. Kompas, 2019. https:// www.kompasiana.com/alvenstony0615/5dacf550097f367d2c413522/progra m-afirmasi-umkm-solusi-bagi-jeritan-umkm?page=all.

Wirayani, Prima. 'Ease of Doing Business RI Turun, Ini Penjelasan Bank Dunia'. CNBC Indonesia, 2018. https://www.cnbcindonesia.com/news/20181031201049-440020/ease-of-doing-business-ri-turun-ini-penjelasan-bank-dunia. 